\title{
Study of perovskite-type oxides and their supported Ag derivatives for catalytic oxidation of diesel soot
}

\author{
Zhiming Liu, ${ }^{1}$ Zhengping Hao, ${ }^{1}$ * Huiping Zhang $^{2}$ and Yahui Zhuang ${ }^{1}$ \\ ${ }^{1}$ Research Center for Eco-Environmental Sciences, Chinese Academy of Sciences, Beijing 100085, People's Republic of China \\ ${ }^{2}$ Department of Chemical Engineering, Xiamen University, Xiamen 361005, People's Republic of China
}

\begin{abstract}
A series of perovskite-type oxides and derived Ag catalysts were prepared, and characterized by $\mathrm{N}_{2}$-adsorption, $\mathrm{X}$-ray diffraction and $\mathrm{X}$-ray photoelectron spectroscopy. The influences of pretreatment and Ag loading on catalytic activity for diesel soot oxidation were also investigated. Prereduction resulted in a decrease in catalytic activity. An increase in activity with Ag addition was observed, especially with more than $5 \%$ Ag loading. This catalyst could be a promising candidate for the catalytic elimination of diesel soot.

(C) 2002 Society of Chemical Industry
\end{abstract}

Keywords: perovskite-type catalysts; supported Ag catalyst; catalytic oxidation; diesel soot

\section{INTRODUCTION}

Emission control from diesel vehicles is a challenging issue. Although three-way catalytic converters for gasoline vehicles have been widely used commercially, their counterparts for diesel vehicles are not yet ready. Soot particles from diesel exhaust are characterized by their small size, more than $70 \%$ of which are smaller than $0.3 \mu \mathrm{m}$. Soot particulates can penetrate into the lungs and they can be a serious health hazard because of the presence of adsorbed hydrocarbons on their

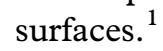

Soot emission from diesel engines can be reduced in various ways, such as by the application of new fuel additives, modifying the structure of diesel engines, and the installation of an exhaust-treatment system. Collection of soot particles in a monolithic filter in combination with simultaneous oxidation seems to be the best option to minimize contamination of the environment. ${ }^{2}$ The following types of catalysts have been tested for the removal of diesel soot: (i) noble and base transition metals; $;^{3-5}$ (ii) oxides and other salts of base transition metals; ${ }^{4,6,7}$ and (iii) compounds of alkali metals. ${ }^{8}$ Application of noble metal catalysts $(\mathrm{Pd}, \mathrm{Pt}, \mathrm{Rh})$ is not practical due to their high costs and their being prone to poisoning. $\mathrm{Cu}-\mathrm{K}-\mathrm{V}-\mathrm{Cl}$ and $\mathrm{Cu}-\mathrm{K}-\mathrm{Mo}-\mathrm{Cl}$ catalysts are thought to be the most active of these types. However, during the course of soot oxidation catalyzed by copper chlorides, $\mathrm{C}-\mathrm{Cl}$ bonds might be formed, and in the presence of oxygen very toxic compounds such as chlorobenzenes and chlorophenols can be produced. For this reason, they are less attractive for practical applications. Recently, perovskite-type oxides were also reported for the catalytic removal of diesel soot. Relatively good initial catalytic activities were found, but relatively little was understood about the factors influencing their catalytic performance.

Generally, perovskite-type oxide catalysts (general formula: $\mathrm{ABO}_{3}$ ) are often used to explore the relationship between the chemical characteristics of the solid and catalytic behavior. Owing to their particular structure, it is possible to produce or suppress oxygen vacancies on the catalyst surface through partial replacement of A or B metallic ions in the lattice. These catalysts are well known for their good performance for the oxidation of $\mathrm{CO}$ and hydrocarbons, and were proposed as substitutes for noble metals in automotive exhaust catalysts. ${ }^{9}$

In this work, a series of perovskite-type oxides and Ag-doped catalysts were prepared by co-precipitation methods. The influences of pretreatment procedure and silver loading on catalytic behavior were studied in detail. It was hoped that the results might be useful for the development of catalytic filters of diesel soot.

\section{EXPERIMENTAL}

\subsection{Catalyst preparation}

Perovskite-type oxide $\mathrm{La}_{0.6} \mathrm{Ce}_{0.4} \mathrm{Co}_{1-x} \mathrm{M}_{x} \mathrm{O}_{3}(\mathrm{M}=\mathrm{Fe}$, $\mathrm{Ni}, \mathrm{Cu}$ ) catalysts were prepared by co-precipitation. $\mathrm{La}\left(\mathrm{NO}_{3}\right)_{3}, \quad \mathrm{Ce}\left(\mathrm{NO}_{3}\right)_{3}, \quad \mathrm{Co}\left(\mathrm{NO}_{3}\right)_{2}, \quad \mathrm{Fe}\left(\mathrm{NO}_{3}\right)_{3}$, $\mathrm{Ni}\left(\mathrm{NO}_{3}\right)_{2}, \mathrm{Cu}\left(\mathrm{NO}_{3}\right)_{2}$ (all in $\mathrm{AR}$ grade purity), in

\footnotetext{
* Correspondence to: Zhengping Hao, Research Center for Eco-Environmental Sciences, Chinese Academy of Sciences, Beijing 100085, People's Republic of China

E-mail: zhengpinghao@ hotmail.com

Contract/grant sponsor: Swedish International Development for Research Cooperation Agency (Sida-AIRPET)

Contract/grant sponsor: China 863 Project
}

(Received 3 May 2001; revised version received 4 December 2001; accepted 13 February 2002) 
calculated amounts, were mixed thoroughly, and the mixed solution was then titrated with sodium carbonate solution. The solution $\mathrm{pH}$ was maintained at 10 . The precipitate was washed with de-ionized water, dried at $120^{\circ} \mathrm{C}$ for $4 \mathrm{~h}$, and then calcined at $900^{\circ} \mathrm{C}$ for $2 \mathrm{~h}$. Catalysts with a perovskite-type structure were thus obtained. Here-in-after $\mathrm{La}_{0.6} \mathrm{Ce}_{0.4} \mathrm{Co}_{1-x} \mathrm{M}_{x} \mathrm{O}_{3}$ $(\mathrm{M}=\mathrm{Fe}, \mathrm{Ni}, \mathrm{Cu})$ catalysts will be indicated as CoM $(\mathrm{M}=\mathrm{Fe}, \mathrm{Ni}, \mathrm{Cu})$.

Ag-doped perovskite-type catalysts were prepared by impregnating each of the host catalysts with an aqueous solution containing a desired amount of $\mathrm{AgNO}_{3}$ (AR grade), followed by drying at $120^{\circ} \mathrm{C}$ for $2 \mathrm{~h}$ and calcining at $500^{\circ} \mathrm{C}$ for $4 \mathrm{~h}$ in air. All catalyst compositions are expressed as weight percentages.

\subsection{Evaluation of catalyst activity}

Evaluation of catalyst activity was performed in a fixed-bed quartz reactor by feeding a gas mixture of $\mathrm{O}_{2}$ $(10 \%)$ and $\mathrm{N}_{2}(90 \%)$ at $100 \mathrm{~cm}^{3} \mathrm{~min}^{-1}$. The catalyst and the soot in a 10:1 weight ratio were well mixed by shaking in a bottle for more than $20 \mathrm{~min}$. The contact between catalyst and soot after mixing was 'loose', 10,11 which is closer to the practical case. Then, $0.22 \mathrm{~g}$ of this catalyst/soot mixture were then placed in a quartztube reactor. The temperature was raised at $3^{\circ} \mathrm{C}$ $\min ^{-1}$ from $200^{\circ} \mathrm{C}$ to $650^{\circ} \mathrm{C}$. The analysis of outlet mixtures was carried out by using an on-line gas chromatograph (SQ-206) equipped with a thermal conductivity detector. A column containing spherical carbon was used to separate $\mathrm{CO}$ and $\mathrm{CO}_{2}$. As the temperature increased more and more $\mathrm{CO}_{2}$ was produced. With time, the concentration of $\mathrm{CO}_{2}$ decreases as the soot burnt out and the conversion reached $100 \%$. Activity is expressed as the temperatures, $T_{50}$ and $T_{90}\left({ }^{\circ} \mathrm{C}\right)$, at which the conversion of the initial diesel soot reaches 50 and $90 \%$ respectively in a temperature programmed oxidation reactor.

Catalysts were preoxidized by feeding $\mathrm{O}_{2}$ at $50 \mathrm{~cm}^{3}$ $\min ^{-1}$ at $700^{\circ} \mathrm{C}$ for $2 \mathrm{~h}$, then cooled. With regard to prereduction of a perovskite-type oxide and its supported Ag derivatives, similar steps were adopted but $\mathrm{H}_{2}$ was fed at $350^{\circ} \mathrm{C}$ instead.

Diesel soot particulate was collected from the tail pipe of the Chinese-made model 195T diesel engine. The amount of adsorbed hydrocarbons was less than $1 \%$. The carbon and hydrogen contents were determined by elemental analysis using CHN CORDER MT-5 equipment (Yanaco), and the results were $89.04 \%$ and $1.15 \%$ respectively.

\subsection{Catalyst characterization}

BET surface areas were measured by $\mathrm{N}_{2}$ adsorption using a ST-03 system. X-ray diffraction (XRD) measurements were carried out on a Rigaku D/MaxRc X-ray Diffractometer with $\mathrm{Cu} \mathrm{K}_{\alpha}$ radiation. Photoelectron spectra (XPS) were acquired with a VG Scientic ESCALAB 220i-XL spectrometer equipped with a hemispherical electron analyzer and $\mathrm{Al} \mathrm{K} \mathrm{K}_{\alpha} \mathrm{X}$-ray source. The powder samples were pressed into small Inox cylinders and then mounted on a sample rod, placed in a pretreatment chamber and outgassed at $250^{\circ} \mathrm{C}$ and $10^{-5}$ Torr for $2 \mathrm{~h}$ prior to being transferred to the analysis chamber. The base pressure in the ion-pumped analysis chamber was maintained below $5 \times 10^{-9}$ Torr. A least-square routine of peak fitting was used for the analysis of XPS spectra. The relative concentrations of chemical elements were calculated by the usual quantification routine, including Wagner's energy dependence of attenuation length and a standard set of the VG Escalab elemental sensitivity factors. The C $1 \mathrm{~s}$ peak was used as a reference.

\section{RESULTS AND DISCUSSION}

\subsection{The influence of pretreatment on the activities of catalysts for diesel soot oxidation}

The activities of catalysts with or without pretreatment were investigated, and the results are shown in Table 1. The temperatures $T_{50}$ and $T_{90}$ of soot oxidation without catalyst are centered at $570^{\circ} \mathrm{C}$ and $605^{\circ} \mathrm{C}$, respectively. It can be seen from Table 1 that $T_{50}$ and $T_{90}$ decreased significantly in the presence of a perovskite catalyst. Catalytic oxidation of diesel soot can be carried out at a lower temperature than the thermal oxidation. The CO selectivity was almost zero. The catalyst CoNi has the highest activity, whereas the catalyst $\mathrm{CoCu}$ has the lowest activity. Törnacrona ${ }^{12}$ reported that for catalysts with rareearth metals and transition metals as promoters, prereduction might alter the lattice oxygen contents and generate oxygen vacancies, which promote their catalytic activities. With the CoM $(\mathrm{M}=\mathrm{Fe}, \mathrm{Ni}, \mathrm{Cu})$ catalysts used in this study, prereduction leads to an apparent decrease in their catalytic activities, contrary to Törnacrona's observation.

\subsection{Catalytic activities of perovskite-type oxide supported Ag catalysts}

Figure 1 shows the relationship between the activity of catalyst $\mathrm{Ag} / \mathrm{Co}$ and the $\mathrm{Ag}$ loading. It is evident that activity is improved by adding $1 \% \mathrm{Ag}$, reaching a maximum at $5 \% \mathrm{Ag}$. The activity of the $\mathrm{Ag} / \mathrm{Co}$ catalyst remained almost unchanged when the Ag loading increased from $5 \%$ to $15 \%$. Therefore, for economic

Table 1. Influence of pretreatment on the activities of catalysts for diesel soot oxidation

\begin{tabular}{|c|c|c|c|c|}
\hline \multirow[b]{3}{*}{ Catalyst } & \multicolumn{4}{|c|}{$\begin{array}{l}\text { Reaction temperature of soot } \\
\text { conversion }\left({ }^{\circ} \mathrm{C}\right)\end{array}$} \\
\hline & \multicolumn{2}{|c|}{$\begin{array}{l}\text { without } \\
\text { pretreatment }\end{array}$} & \multicolumn{2}{|c|}{$\begin{array}{l}\text { with } \\
\text { prereduction }\end{array}$} \\
\hline & $T_{50}$ & $T_{90}$ & $T_{50}$ & $T_{90}$ \\
\hline $\mathrm{La}_{0.6} \mathrm{Ce}_{0.4} \mathrm{CoO}_{3}$ & 436 & 509 & 479 & 527 \\
\hline $\mathrm{La}_{0.6} \mathrm{Ce}_{0.4} \mathrm{Ni}_{0.5} \mathrm{Co}_{0.5} \mathrm{O}_{3}$ & 421 & 512 & 476 & 529 \\
\hline $\mathrm{La}_{0.6} \mathrm{Ce}_{0.4} \mathrm{Cu}_{0.5} \mathrm{Co}_{0.5} \mathrm{O}_{3}$ & 454 & 524 & 484 & 535 \\
\hline $\mathrm{La}_{0.6} \mathrm{Ce}_{0.4} \mathrm{Fe}_{0.5} \mathrm{Co}_{0.5} \mathrm{O}_{3}$ & 433 & 520 & 478 & 525 \\
\hline
\end{tabular}




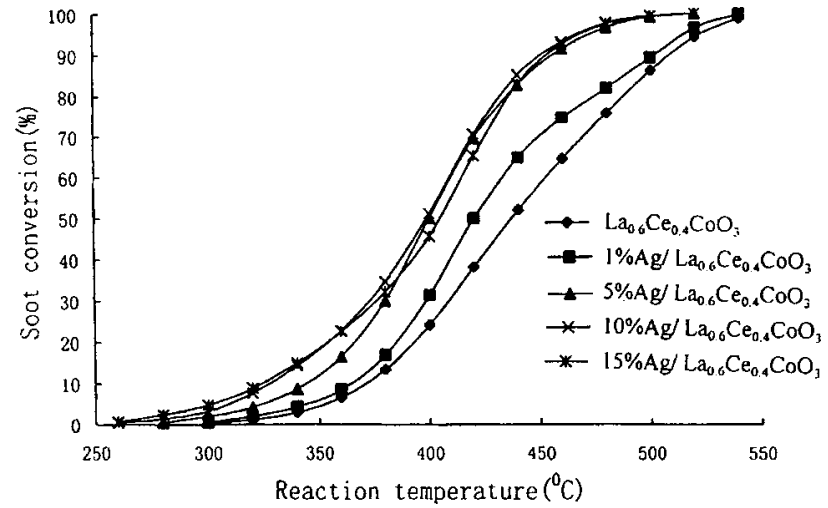

Figure 1. Activities of various $\mathrm{Ag} / \mathrm{La}_{0.6} \mathrm{Ce}_{0.4} \mathrm{CoO}_{3}$ catalysts for soot oxidation at different reaction temperatures.

reasons, the optimal Ag loading of this kind of catalyst is $5 \%$.

The activity of the $\mathrm{CoM}(\mathrm{M}=\mathrm{Fe}, \mathrm{Ni}, \mathrm{Cu})$ catalyst is still relatively low, but is improved by adding Ag. The difference due to changing the nature of $M$ is small. The results for the $5 \% \mathrm{Ag} / \mathrm{CoM}(\mathrm{M}=\mathrm{Fe}, \mathrm{Ni}, \mathrm{Cu})$ catalysts are shown in Fig 2 and Table 2. The catalyst $5 \% \mathrm{Ag} / \mathrm{Co}$ has the highest activity. In addition, activity is significantly decreased by prereduction.

It can be seen from Table 3 that the activities of the $5 \% \mathrm{Ag} / \mathrm{CoM}(\mathrm{M}=\mathrm{Fe}, \mathrm{Ni}, \mathrm{Cu})$ catalysts were also markedly decreased due to preoxidation at $700^{\circ} \mathrm{C}$. This suggests that the stability of a perovskite-type oxide supported Ag catalyst is relatively low.

\subsection{Characterization of perovskite-type oxide supported Ag catalysts}

From Table 4, we can see that BET surface area of a perovskite-type oxide and its supported Ag catalyst is very low. It is similar to the observation of Taguchi et al. ${ }^{13}$ Calcination at high temperatures is necessary to obtain a perovskite-type oxide catalyst, but such treatment often results in a dramatic decrease in the surface area.

Figure 3 shows the XRD patterns of the catalysts Co and $5 \% \mathrm{Ag} / \mathrm{Co}$. Their diffraction peaks are similar to those of $\mathrm{LaCoO}_{3}$, which is typical of a perovskite-type

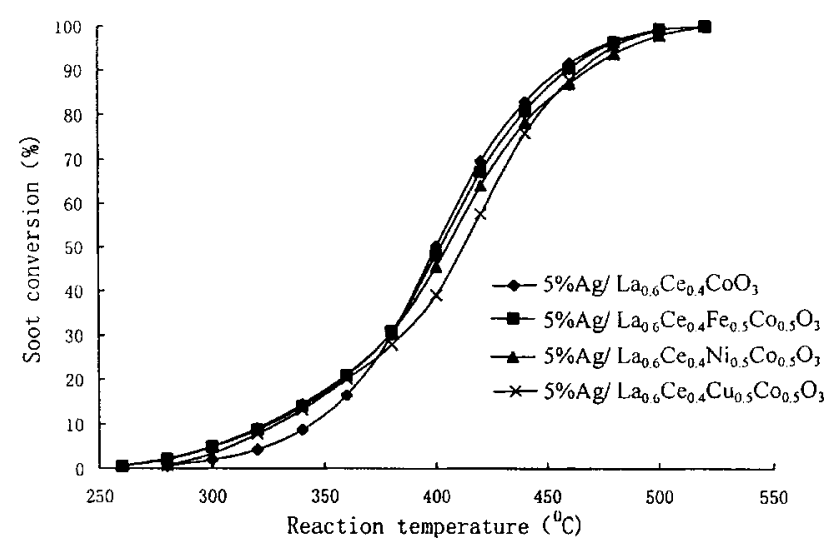

Figure 2. Activities of $5 \% \mathrm{Ag} / \mathrm{La}_{0.6} \mathrm{Ce}_{0.4} \mathrm{Co}_{1-x} \mathrm{M}_{x} \mathrm{O}_{3}(\mathrm{M}=\mathrm{Fe}, \mathrm{Ni}, \mathrm{Cu})$ catalysts for soot oxidation at different reaction temperatures.
Table 2. Catalytic activities of perovskite-type oxide supported Ag catalysts

\begin{tabular}{|c|c|c|}
\hline \multirow[b]{2}{*}{ Catalyst } & \multicolumn{2}{|c|}{$\begin{array}{c}\text { Reaction temperature of } \\
\text { soot conversion }\left({ }^{\circ} \mathrm{C}\right)\end{array}$} \\
\hline & $T_{50}$ & $T_{90}$ \\
\hline $1 \% \mathrm{Ag} / \mathrm{La}_{0.6} \mathrm{Ce}_{0.4} \mathrm{CoO}_{3}$ & 420 & 502 \\
\hline $5 \% \mathrm{Ag} / \mathrm{La}_{0.6} \mathrm{Ce}_{0.4} \mathrm{CoO}_{3}$ & 400 & 456 \\
\hline $10 \% \mathrm{Ag} / \mathrm{La}{ }_{0.6} \mathrm{Ce}_{0.4} \mathrm{CoO}_{3}$ & 398 & 452 \\
\hline $15 \% \mathrm{Ag} / \mathrm{La}_{0.6} \mathrm{Ce}_{0.4} \mathrm{CoO}_{3}$ & 404 & 455 \\
\hline $5 \% \mathrm{Ag} / \mathrm{La}_{0.6} \mathrm{Ce}_{0.4} \mathrm{Fe}_{0.5} \mathrm{Co}_{0.5} \mathrm{O}_{3}$ & 402 & 459 \\
\hline $5 \% \mathrm{Ag} / \mathrm{La}_{0.6} \mathrm{Ce}_{0.4} \mathrm{Ni}_{0.5} \mathrm{Co}_{0.5} \mathrm{O}_{3}$ & 405 & 469 \\
\hline $5 \% \mathrm{Ag} / \mathrm{La}_{0.6} \mathrm{Ce}_{0.4} \mathrm{Cu}_{0.5} \mathrm{Co}_{0.5} \mathrm{O}_{3}$ & 412 & 466 \\
\hline $\begin{array}{l}5 \% \mathrm{Ag} / \mathrm{La}_{0.6} \mathrm{Ce}_{0.4} \mathrm{Ni}_{0.5} \mathrm{Co}_{0.5} \mathrm{O}_{3} \\
\text { (prereduced) }\end{array}$ & 493 & 544 \\
\hline
\end{tabular}

Table 3. Influence of preoxidation on the activities of perovskite-type oxide supported Ag catalysts for diesel soot oxidation

\begin{tabular}{lcc}
\hline & \multicolumn{2}{c}{$\begin{array}{c}\text { Reaction temperature of } \\
\text { soot conversion }\left({ }^{\circ} \mathrm{C}\right) \text { with } \\
\text { preoxidation }\end{array}$} \\
\cline { 2 - 3 } Catalyst & $T_{50}$ & $T_{90}$ \\
\hline $5 \% \mathrm{Ag} / \mathrm{La}_{0.6} \mathrm{Ce}_{0.4} \mathrm{CoO}_{3}$ & 443 & 511 \\
$5 \% \mathrm{Ag} / \mathrm{La}_{0.6} \mathrm{Ce}_{0.4} \mathrm{Ni}_{0.5} \mathrm{Co}_{0.5} \mathrm{O}_{3}$ & 439 & 504 \\
$5 \% \mathrm{Ag} / \mathrm{La} \mathrm{a}_{0.6} \mathrm{Ce}_{0.4} \mathrm{Cu}_{0.5} \mathrm{Co}_{0.5} \mathrm{O}_{3}$ & 449 & 507 \\
$5 \% \mathrm{Ag} / \mathrm{La}_{0.6} \mathrm{Ce}_{0.4} \mathrm{Fe}_{0.5} \mathrm{Co}_{0.5} \mathrm{O}_{3}$ & 437 & 502 \\
\hline
\end{tabular}

oxide structure. In addition, diffraction peaks ascribed to $\mathrm{CeO}_{2}$ can be observed. There is no conclusive evidence for the existence of a crystalline phase for $\mathrm{Ag}^{0}$ or $\mathrm{Ag}_{2} \mathrm{O}$ in the $5 \% \mathrm{Ag} / \mathrm{Co}$ catalyst, this means that $\mathrm{Ag}$ is highly dispersed.

Surface structures of the three catalysts $\mathrm{CoNi}, 5 \%$ $\mathrm{Ag} / \mathrm{CoNi}$ and $5 \% \mathrm{Ag} / \mathrm{CoNi}$ (pre-reduced) were analyzed by XPS and the results are shown in Table 5 . The C1s level shows three peaks at $284.6 \mathrm{eV}$ and $285.4 \mathrm{eV}$ (carbon contamination) and $288.6 \mathrm{eV}$ (due to the presence of surface carbonates). ${ }^{14}$ The O1s signal was deconvoluted in three peaks: (I) $527.5-529.5 \mathrm{eV}$, (II) $530-531.5 \mathrm{eV}$ and (III) above $532 \mathrm{eV}$. Peak (I) corresponds to lattice oxygen $\left(\mathrm{O}^{2-}\right)$, whereas peak (II) is assigned to both hydroxide $\left(\mathrm{OH}^{-}\right)$and carbonate $\left(\mathrm{CO}_{3}^{2-}\right)$ species, peak (III) is associated with adsorbed molecular water. ${ }^{15-18}$ The binding energy (BE) value of $\mathrm{Ag}\left(3 \mathrm{~d}_{5 / 2}\right)$ before reduction is $367.4 \mathrm{eV}$,

Table 4. The specific surface area of different catalysts

\begin{tabular}{lc}
\hline Catalyst & $\begin{array}{c}\text { Specific surface } \\
\text { area }\left(\mathrm{m}^{2} \mathrm{~g}^{-1}\right)\end{array}$ \\
\hline $\mathrm{La}_{0.6} \mathrm{Ce}_{0.4} \mathrm{CoO}_{3}$ & 3.7 \\
$\mathrm{La}_{0.6} \mathrm{Ce}_{0.4} \mathrm{Ni}_{0.5} \mathrm{Co}_{0.5} \mathrm{O}_{3}$ & 3.1 \\
$\mathrm{La}_{0.6} \mathrm{Ce}_{0.4} \mathrm{Fe}_{0.5} \mathrm{Co}_{0.5} \mathrm{O}_{3}$ & 7.4 \\
$\mathrm{La}_{0.6} \mathrm{Ce}_{0.4} \mathrm{Cu}_{0.5} \mathrm{Co}_{0.5} \mathrm{O}_{3}$ & 4.5 \\
$5 \% \mathrm{Ag} / \mathrm{La}{ }_{0.6} \mathrm{Ce}_{0.4} \mathrm{CoO}_{3}$ & 1.8 \\
$5 \% \mathrm{Ag} / \mathrm{La}_{0.6} \mathrm{Ce}_{0.4} \mathrm{Ni}_{0.5} \mathrm{Co}_{0.5} \mathrm{O}_{3}$ & 1.2 \\
$5 \% \mathrm{Ag} / \mathrm{La}_{0.6} \mathrm{Ce}_{0.4} \mathrm{Fe}_{0.5} \mathrm{Co}_{0.5} \mathrm{O}_{3}$ & 3.2 \\
$5 \% \mathrm{Ag} / \mathrm{La}{ }_{0.6} \mathrm{Ce}_{0.4} \mathrm{Cu}_{0.5} \mathrm{Co}_{0.5} \mathrm{O}_{3}$ & 3.5 \\
\hline
\end{tabular}




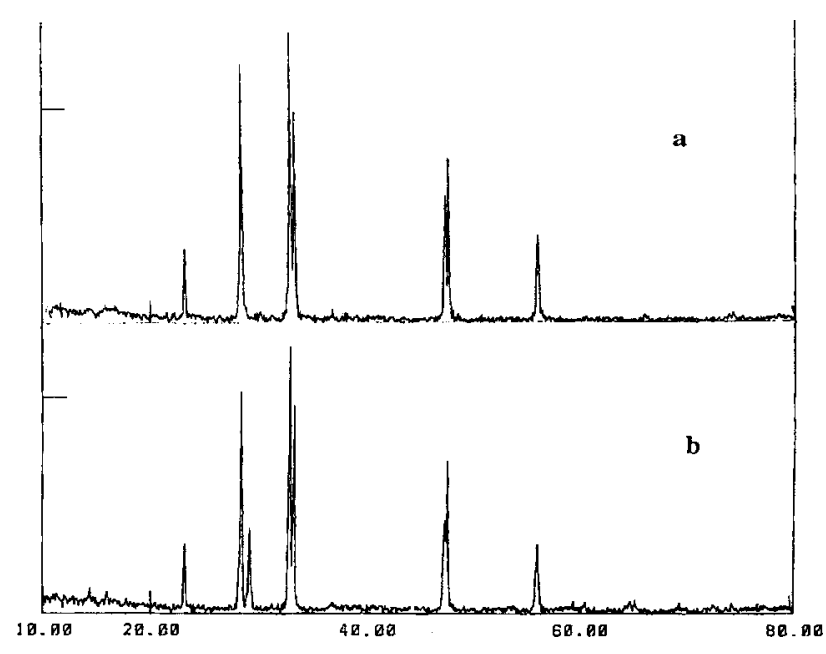

Figure 3. XRD patterns of $\mathrm{La}_{0.6} \mathrm{Ce}_{0.4} \mathrm{CoO}_{3}(\mathrm{a})$ and $5 \% \mathrm{Ag} / \mathrm{La}_{0.6} \mathrm{Ce}_{0.4} \mathrm{CoO}_{3}$ (b) catalysts.

which was consistent with that assigned to $\mathrm{Ag}^{+}\left(3 \mathrm{~d}_{5 / 2}\right)$ in the literature. ${ }^{19,20}$ There is no evidence for the existence of $\mathrm{Ag}^{0}(\mathrm{BE}=368.2 \mathrm{eV})$. We found that the Ag surface species in $\mathrm{CoM}(\mathrm{M}=\mathrm{Fe}, \mathrm{Ni}, \mathrm{Cu})$ supported $\mathrm{Ag}$ catalysts was $\mathrm{Ag}^{+}$. Perhaps some of the $\mathrm{Ag}^{+}$doped on to the surface of CoM partially occupied the sites of $\mathrm{La}^{3+}$ due to their similar ionic radii, and thus became stabilized by the perovskite lattice, which would contribute to the prevention of silver aggregation on the surface and enhance the stability of the catalyst. At the same time, $\mathrm{Ag}^{+}$also induces some Schottky defects in the form of anionic vacancies, which would be favorable for the adsorption-activation of oxygen on the functioning catalyst and the transport of the lattice and surface oxygen species. All these factors would contribute to the improvement of the activities of these perovskite-type catalysts. Thermodynamically, $\mathrm{Ag}^{+}$will be reduced and become metallic $\mathrm{Ag}$ in $\mathrm{H}_{2}$ at $350^{\circ} \mathrm{C}$, however, in the case of the $5 \% \mathrm{Ag} / \mathrm{CoNi}$ catalyst, the metallic $\mathrm{Ag}$ pattern did not appear, judging from the $\mathrm{BE}$ value of $\mathrm{Ag}\left(3 \mathrm{~d}_{5 / 2}\right)(367.6 \mathrm{eV})$ after reduction.

\section{CONCLUSION}

The catalytic oxidations of diesel soot over perovskite- type oxides and derived Ag catalysts were investigated. The activities of the catalysts were decreased with prereduction treatment, while they were pronouncedly improved by adding Ag. The optimal Ag loading is about $5 \%$. Judging from the XRD characterization of Co and 5\% Ag/Co catalysts, and also from the XPS result of the $5 \% \mathrm{Ag} / \mathrm{CoNi}$ catalyst, we can conclude that highly dispersed $\mathrm{Ag}^{+}$played an important role in improving the catalytic activities of these perovskitetype supported Ag catalysts. Prereduction results in a decrease of the activities of $5 \% \mathrm{Ag} / \mathrm{CoM}$ catalysts.

\section{ACKNOWLEDGEMENTS}

Partial financial support from the Swedish International Development for Research Cooperation Agency (Sida-AIRPET) and China 863 Project is greatly appreciated.

\section{REFERENCES}

1 Heller K, Clean air: a fresh challenge. Chemical Week 149(16):2223 (1991)

2 Mul Guido, Neeft John PA, Kapteijn Freek and Makkee Michiel, Soot oxidation catalyzed by a $\mathrm{Cu} / \mathrm{K} / \mathrm{Mo} / \mathrm{Cl}$ catalyst: evaluation of the chemistry and performance of the catalyst. Appl Catal 6:339-352 (1995)

3 Uchisawa Junko Oi, Obuchi Akira, Zhao Zhen and Kushiyama Satoshi, Carbon oxidation with platinum supported catalysts. Appl Catal 18:183-187 (1998).

4 Ahlstrom AF and Odenbrand CUI, Catalytic combustion of soot deposits from diesel engines. Appl Catal 60:143-156 (1990).

5 Ahlstrom AF and Odenbrand CUI, Combustion of soot deposits from diesel engines on mixed oxides of vanadium pentoxide and cupric oxide. Appl Catal 60:157-172 (1990).

6 McKee DW, The copper-catalyzed oxidation of graphite. Carbon 8:131-139 (1970).

7 Mckee DW, Metal oxides as catalysts for the oxidation of graphite. Carbon 8:623-635 (1970).

8 Mckee DW and Chatterii D, The catalytic behavior of alkali metal carbonates and oxides in graphite oxidation reactions. Carbon 13:381-390 (1975).

9 Teraoka Y, Nakano K, Kagawa S and Shaangguan WF, Simulaneous removal of nitrogen oxides and diesel soot particulates catalyzed by perovskite-type oxides. Appl Catal 5:181-185 (1995).

10 Neeft JPA, Make $M$ and Malign JA, Catalysts for the oxidation of soot from diesel exhaust gas. I-an exploratory study. Appl Catal 8:57-78 (1996).

11 Neeft JPA, Pruissen OP, Makkee M and Moulijn A, Catalysts for

Table 5. Binding energy $(\mathrm{eV})$ of surface elements and surface chemical composition of different catalysts

\begin{tabular}{|c|c|c|c|c|c|c|c|c|c|c|}
\hline \multirow[b]{2}{*}{ Catalyst } & \multicolumn{5}{|c|}{$B E(e V)$} & \multicolumn{5}{|c|}{ Content (\%) } \\
\hline & $\operatorname{La}\left(3 d_{5 / 2}\right)$ & $\operatorname{Ce}\left(3 d_{5 / 2}\right)$ & $\operatorname{Co}\left(2 p_{3 / 2}\right)$ & $O(1 s)$ & $\operatorname{Ag}\left(3 d_{5 / 2}\right)$ & $\mathrm{La}$ & $\mathrm{Ce}$ & Co & 0 & $A g$ \\
\hline $\mathrm{La}_{0.6} \mathrm{Ce}_{0.4} \mathrm{Ni}_{0.5} \mathrm{Co}_{0.5} \mathrm{O}_{3}$ & 833.7 & 881.6 & 779.7 & $\begin{array}{l}528.4 \\
530.5 \\
531.8\end{array}$ & - & 12.7 & 5.9 & 4.0 & 77.4 & - \\
\hline $5 \% \mathrm{Ag} / \mathrm{La}_{0.6} \mathrm{Ce}_{0.4} \mathrm{Ni}_{0.5} \mathrm{Co}_{0.5} \mathrm{O}_{3}$ & 833.4 & 881.6 & 779.3 & $\begin{array}{l}528.3 \\
530.6 \\
533.3\end{array}$ & 367.4 & 10.2 & 4.6 & 5.4 & 76.1 & 3.7 \\
\hline $5 \% \mathrm{Ag} / \mathrm{La}_{0.6} \mathrm{Ce}_{0.4} \mathrm{Ni}_{0.5} \mathrm{Co}_{0.5} \mathrm{O}_{3}$ (prereduced) & 833.8 & 881.6 & 779.5 & $\begin{array}{l}528.2 \\
530.4 \\
532.3\end{array}$ & 367.6 & 2.1 & 1.5 & 2.6 & 92.8 & 1.0 \\
\hline
\end{tabular}


the oxidation of soot from diesel exhaust gases. II-Contact between soot and catalyst under practical conditions. Appl Catal 12:21-31 (1997).

12 Törncrona A, Skoglundh M, Thormählen P, Fridell E and Jobson E, Low temperature catalytic activity of cobalt oxide and ceria promoted Pt and Pd:-Influence of pretreatment and gas composition. Appl Catal 14:131-146 (1997).

13 Taguchi H, Matsuda D and Nagao M, Surface characterization of $\left(\mathrm{La}_{1-x} \mathrm{Sr}_{x}\right) \mathrm{MnO}_{3}$ synthesized using a sol-gel process and solid-state reaction. Fournal of Materials Science Letters 14:1214 (1995).

14 Ponce S, Peña MA and Fierro JLG, Surface properties and catalytic performance in methane combustion of Sr-substitued lanthanum manganites. Appl Catal B 24:193-205 (2000).

15 Lombardo EA, Kazunori T and Isamu T, XPS characterization of reduced $\mathrm{LaCoO}_{3}$ perovskite. f Catal 80:340-349 (1983).

16 Gunasekaran N, Rajadurai S, Caberry JJ, Bakshi N and Alcock
CB, Surface characterization and catalytic properties of $\mathrm{La}_{1-x} \mathrm{~A}_{x} \mathrm{MO}_{3}$ perovskite type oxides, Part I. Studies on $\mathrm{La}_{0.95} \mathrm{Ba}_{0.05} \mathrm{MO}_{3}(\mathrm{M}=\mathrm{Mn}, \mathrm{Fe}$ or Co)oxides. Sol State Ion 73:289-295 (1994).

17 Taguchi H, Sugita A and Nagao M, Surface characterization of $\mathrm{LaMnO}_{3+\sigma}$ powder annealed in air. $\mathcal{F}$ Sol State Chem 119:164168 (1995).

18 Tabata K, Matsumato I and Kohihi S, Surface characterization and catalytic properties of $\mathrm{La}_{1-x} \mathrm{Sr}_{x} \mathrm{CoO}_{3} . \mathcal{F}$ Mater Sci 22:18821886 (1989).

19 Watanabe $\mathrm{N}$, Yamashita $\mathrm{H}$ and Miyadera $\mathrm{H}$, Removal of unpleasant odor gases using an Ag-Mn catalyst. Appl Catal 8:405-416 (1996).

20 Sano Taizo, Negishi Nobuaki, Mas Denis and Takeuchi Koji, Photocatalytic decomposition of $\mathrm{N}_{2} \mathrm{O}$ on highly dispersed $\mathrm{Ag}^{+}$ ions on $\mathrm{TiO}_{2}$ prepared by photodeposition. f Catal 194:71-79 (2000). 